Article

\title{
Can ESG Performance Affect Bond Default Rate? Evidence from China
}

\author{
Peixin Li®, Rongxi Zhou and Yahui Xiong *
}

School of Finance and Banking, University of International Business and Economics, Beijing 100029, China; lpx0504@126.com (P.L.); zhourx@uibe.edu.cn (R.Z.)

* Correspondence: 201700240049@uibe.edu.cn; Tel.: +86-10-6449-3082

Received: 21 February 2020; Accepted: 26 March 2020; Published: 7 April 2020

\begin{abstract}
Capturing determinants of bond default risks has aroused heated discussions ever since the "rigid payment" system collapsed in China. Within this context; this paper aims to clarify the relation between an issuer's environmental; social; and corporate (ESG) performance and its bond default rate. We developed an ESG factors-embedded Logistic Regression model to empirically examine Chinese default bonds and outstanding industrial bonds from 2014 to 2019. Results indicate that the bond default rate is positively correlated with the company's energy consumption and negatively correlated with its attention to social responsibilities; and corporate governance; in addition to its financial performances. In conclusion; to fully take ESG factors into consideration during the decision-making process and daily operations might improve stability and credibility of corporations in modern Chinese national context.
\end{abstract}

Keywords: ESG performance; bond default rate; logistic regression model; financial performance

\section{Introduction}

Ever since Chaori's Bond (112061) defaulted in March 2014, the first corporate bond default in China, the bond default rate has escalated, ending the golden era of guaranteed payment (also known as 'rigid payment'). Under these circumstances, developing a clear and consistent bond default risk model in the Chinese capital market would provide valuable referential information not only for investors but also for pricing and rating agencies.

Previous researches have long attempted to build models to quantify possibilities and to reveal essential reasons for bond defaults. Early studies, including that of Kolari and Apilado, concluded that financial performance, measured as a series of accounting ratios of the issuer, dramatically influences the solvency of the corporation and works as an independent variable in the default rate prediction model [1]. Likewise, Huffman and Ward highlighted that defaults on high yield bonds are associated with higher asset growth rates, lower operating profit margins, larger levels of collateralizable assets, and larger volatility rates in net working capital [2]. However, limited by both the accessibility of environmental performance, social responsibility, and corporate governance (hereafter ESG) data and the neglect of sustainable development, early researches focused too much on presenting criteria and theories derived solely from financial or accounting indicators of bond issuers, rather than from daily operations and internal features of each corporation sample.

Sustainable development has not only become an essential part of the government's governance and enterprise development but also been an academic focus [3]. Specific to enterprise development, environmental, social responsibility, and corporate governance (ESG) are increasingly becoming a consensus $[4,5]$. Several papers relate to recent studies advancing the proposition that the sustainable investing process should consider the overall ESG scores, all ESG pillars, and even the links between 
them [6-8]. With the gradual pace of the global popularization of the ESG framework, scholars are now more aware of the impact of ESG performance on corporate financial behavior.

Relevant research and empirical results have been mainly from American data. From the environmental perspective, studies noted that better environmental risk management correlates with lower capital cost, since it might result in a lower beta of the corporation, higher resource utilization, and favorable tax benefits $[9,10]$. Chava, on the other hand, conducted empirical research to provide concrete evidences that investors in the capital market do really value the borrower's environmental externalities from specific aspects, including environmental concerns and strengths, waste emission, and actions in pollution prevention [11]. To be more specific, debtholders are more cautious about the corporation's environmental performance if the corporation faces higher environmental risks, which might lead to bankruptcy risks [12].

Social responsibility, which can be perceived as an investment in fostering trust between the company and stakeholders, is also crucial in guaranteeing stable or satisfying financial revenue and lower business risks. Lins et al. pointed out that firms that have a stronger sense of corporate social responsibility (CSR) have higher stock returns as well as better financial performance during economic crises [13]. In other words, investments in CSR might provide a buffer for the company during business downswings. From the perspective of capital cost, Ghoul et al. examined the effect of CSR on the cost of equity for US firms and found that firms with better CSR scores enjoy lower equity cost while firms which participate in tobacco and nuclear power production bear higher costs [14]. Researchers concluded that corporate bond yield spreads are in correlation with CSR performance as well, since high-CSR performance corporations are generally granted higher credit ratings during issuance [15-17]. For bank loans, similar conclusions have been drawn that corporations with worse CSR performance and greater CSR uncertainty might face higher loan spreads [18]. Better CSR performance corporations are generally more transparent in disclosing corporation information, and attach importance to constraints and bond covenants $[19,20]$, which might help to bring down agency costs and issuing costs [21].

Better corporate governance also serves as a factor that might reduce capital costs [22,23], since internal governance disclosure might mitigate information and agency costs [24] through reducing information asymmetry [25] and inducing effective monitoring [26]. Specifically, corporations reporting a large sum of unaudited earnings have a higher cost of equity, while those that have gone through independent audits have a lower cost of equity [27]. Meanwhile, the board structure of the firm is also a vital determinant when predicting the possibility of bankruptcy, CEOs serve simultaneously as board chairpersons reduces board effectiveness [28], since less board independence correlates with higher default risks [29].

As analyzed above, because of their short-sighted production behaviors, corporations which bring about side-effects of severe pollution, information asymmetry, or negative externalities during their daily operations, encounter higher capital costs and lower profit margins from rigorous environmental regulations and punishments. These factors pose threats to the survival of these corporations, especially during the period of Structural Transformation in China. They might lead to reputational risks [30], regulation risks, and strategic risks, resulted in increased difficulties in funding and repayment. In contrast, those corporations in environmentally friendly, highly differentiated industries possess lower default risks, lower capital costs [31], and proper corporate governance [32]. Besides, Christopher and $\mathrm{Li}$ investigated whether the ratings of employee dimension in Morgan Stanley Capital International (MSCI) ESG database reflect employee performance of a firm [33]. Therefore, on-schedule repayment is also based on well-managed ESG governance, which can be divided into three aspects: satisfying environmental performance, strong sense of social responsibilities, and stable corporate governance.

This paper aims at investigating the impact of industrial bond issuers' ESG governance and financial performance on default risk. We have picked up the 62 defaulted industrial bonds and randomly chosen 85 outstanding non-default industrial bonds with detailed financial disclosures to form the control group. A Logistic Regression model was then applied in evaluating the default possibility 
of each issue of sample bond. In our model, the environmental performance, social responsibility, corporate characteristics, and financial ratios work as independent variables, while whether the bond is defaulted is the dependent variable.

This research provides a more complete and robust way to estimate the insolvency of industrial bonds in China. The main contribution is that this paper presents a method of analyzing the ESG governance level under the restriction of available statistics. Rather than considering financial ratios as the only determinants, this paper develops a comprehensive and coherent model concerning both ESG factors and accounting indicators.

The next section will discuss sample construction and descriptive statistics of chosen factors and indicators. The methodology of this research will then be presented with a demonstration of the calculation result. The robustness and predictability of the model will be presented with a summary of significance tests as well as a practical test on the Holdout Sample. At the end of the paper, conclusions will be drawn, and the implications of this model will be provided.

\section{Data and Sample}

\subsection{Sample Construction}

Samples used in this research consist of industrial bonds issued in the period of 2011-2019. To ensure homogeneity and facilitate further computation, all these samples were vanilla bonds (i.e., nonconvertible, non-callable, non-puttable, and consist of no additional terms), and are bonds of which the issuer should disclose detailed financial information as well as some ESG information. The issuer's characteristics (i.e., privately owned or not) and expected use of the capital raised by the issuance should be consistent and coherent throughout the entire maturity.

More than 1200 issuances of non-default industrial bonds satisfy the criteria mentioned above, 85 of which are randomly selected to form the control group. Since the first bond default in China took place recently, there have been only 315 bond defaults in total, among which 62 issuances are chosen here to be classified as the default group.

As Table 1 shows, each group is then randomly divided into two groups. "Estimation Sample" consists of about $2 / 3$ of the total samples, and remainders are categorized into "holdout sample", which are later tested to verify the accuracy of the model. Specifically, 57 issuances of non-default bonds and 42 issuances of default bonds form the Estimation Sample, which occupies $57.58 \%$ of the total samples, whereas 28 issuances of non-default bonds and 20 issuances of default bonds construct the Holdout Sample, which is $42.18 \%$ of the total. None of the issues in the Estimation Sample are re-classified into the holdout ones, i.e., the intersection of these two groups is a null set.

Table 1. Classification of samples.

\begin{tabular}{cccccc}
\hline \multirow{2}{*}{ Sample } & \multicolumn{2}{c}{ Control Group } & \multicolumn{2}{c}{ Default Group } & \multirow{2}{*}{ Total } \\
\cline { 2 - 4 } & Number & \% of Group & Number & \% of Group & \\
\hline Estimation Sample & 57 & $57.58 \%$ & 42 & $42.42 \%$ & 99 \\
Holdout Sample & 28 & $58.33 \%$ & 20 & $41.67 \%$ & 48 \\
Total & 85 & $57.82 \%$ & 62 & $42.18 \%$ & 147 \\
\hline
\end{tabular}

\subsection{Factors and Corresponding Indicators}

Factors that are employed in this model can be divided into two classes. The first one, which is the innovative part of the research, involves measures that quantify the ESG performance of the corporation. The second investigates the financial status of the corporation, which, to a certain degree, resembles the relevant prior studies. A summary of all factors and corresponding indicators is listed in Table 2. 
Table 2. Summary of factors and corresponding indicators.

\begin{tabular}{|c|c|c|c|}
\hline Factors & Indicators & Symbols & Formula \\
\hline $\begin{array}{l}\text { Environmental } \\
\text { Performance }\end{array}$ & Standard Energy Consumption & SEC & $\begin{array}{l}\text { Total Standard Energy Consumption } \\
\text { of the Industry/GDP of the Industry }\end{array}$ \\
\hline Social Responsibility & $\begin{array}{c}\text { Social Responsibility Building } \\
\text { Disclosure }\end{array}$ & SRBD & Disclosed $=1$, Nondisclosed $=0$ \\
\hline Corporate Governance & Corporation Characteristics & $\mathrm{CC}$ & Private Enterprise $=1$, Else $=0$ \\
\hline Leverage & Asset Liability Ratio & ALR & Total Liabilities / Total Assets \\
\hline Profitability & Net Income Ratio & NIR & $\begin{array}{l}\text { Net Income/ 3-year Geometric } \\
\text { Average of the Total Sales Income }\end{array}$ \\
\hline Growth & Fixed Investment Growth Rate & FIGR & $\begin{array}{l}\text { Growth Rate of Fixed Investment } \\
\text { Newly Added to the Industry }\end{array}$ \\
\hline
\end{tabular}

\subsubsection{ESG Factors}

In recent years there has been a robust international escalation in research on environmental, social, and corporate governance (ESG) issues [34-37]. ESG refers to environmental performance, social responsibility, and corporate governance. ESG factors are/should be considered by issuers in their overall business strategy and investors are integrating ESG criteria into investment and decision-making practices [38-40]. However, due to the absence of standardized and mandatory micro-level ESG disclosure regulation in the Chinese bond market, proxies for these factors can be severely limited and deficient, resulting from challenges in finding and constructing multi-dimensional ESG factors. Taking this particular situation into consideration, this study develops a series of indicators to reveal or at least approximate the actual ESG governance status in each corporation.

According to the Sustainable Development Theory, which was elaborated in the groundbreaking report Agenda 21, in order to obtain a more sustainable long-term economic growth, those industries that lack technological innovation and are prone to consume relatively too much natural and human resources in generating economic benefits, are bound to be gradually eliminated or forced to go through transitions. In this sense, a corporation that is directly exposed to excessive-production industries or that does not comply with environmentally friendly principles, is likely to end up in financial distress. Since corporation-leveled, homogeneous, standardized, and publicly available indicators that estimate environmental efficiency have yet to be compiled, this research quantifies this factor using the average Standard Energy Consumption (SEC) of the industry of the issuer. SEC is calculated as below:

$$
S E C_{i}=\frac{\text { Total Standard Energy Consumption of Industry }}{\text { GDP of Industry }}
$$

Supposedly, corporations with higher SEC tend to perform worse than those "cleaner" corporations. However, since higher energy consumption would inevitably bring about greater energy expenditures, resulting in a significant increase in total cost and a probable decrease in net income, the importance of selecting a financial variable that controls differences in net income ratios is explicit: it helps to distinguish whether the influence of energy consumption on bond default rate is posed by affecting environmental performance or financial performance.

The Stakeholder Theory [41] mentioned, in addition to stockholders, creditors and management personnel, employees, upstream and downstream businesses and institutions, and regulating agencies also influence corporation operation and management. A legitimate and transparent management framework does good to the local communities and even the whole society, eventually the corporation might benefits from its established reputation. Therefore, corporate social responsibility sometimes can be a powerful, even crucial factor that the corporation should not overlook. To estimate the level of social responsibility governance of bond issuers, we apply a dummy variable. Social Responsibility Building Disclosure (SRBD) is used to show whether relevant information has been presented in the issuer's financial statement, where 1 means yes and 0 means no. Such data can be found on the China Stock Market \& Accounting Research Database (CSMAR). 
State-owned enterprises, which are commonly taken as pillar enterprises in nearly every industry in China, are inherently interlinked with the government. Under such circumstances, these corporations are naturally capable of acquiring, mobilizing, and allocating significantly more resources than private enterprises. Private enterprises tend to have weaker connections with the government or authorities and capture smaller market shares, so they might have less standard risk management systems, slimmer availabilities of market and capital resources [42], more unbalanced corporate governance, and more unfavorable, even hostile market conditions. Thus, they are prone to under-perform and default. Corporation Characteristics (CC) is defined as a dummy variable where 1 stands for private enterprise while 0 stands for other characters.

\subsubsection{Financial Ratios}

In reference to financial status of the issuer, this model mainly selects a series of typical and representative accounting ratios. These ratios can be roughly classified into three columns. One of the most widely used measures for leverage is Asset Liability Ratio (ALR). Corporations with higher Asset Liability Ratios are more likely to default during a business downswing. The profitability variable is employed to estimate the profit rate of the corporation and address the potential possibility that SEC affects the bond default rate mainly because of its influence on corporation cost and profit, rather than corporation environmental performance and sustainability. Net Income Ratio (NIR) is a widely used ratio to compare the profitability of corporations within or among industries. Corporations that enjoy remarkable growth or exist in rising and vibrant industries are expected to make bond interest payments on schedule in the following years, as they will have set off on the fast lane. The most perceivable proxy for the growth factor is the Operating Income Growth Rate. However, this indicator can be heavily biased or at least distorted as the market fluctuates each year, making this indicator drastically volatile on a year-on-year basis. Therefore, in this model, we employ Fixed Investment Growth Rate (FIGR) to illustrate not only the overall growth rate of the industry that the issuer belongs to, but also the external features and comprehensive information including policy and market trend. Fixed Investment Growth Rate (FIGR) is defined as the 3-year geometric average of the fixed investment growth rate newly added to the industry.

To verify that the correlation between each pair of variables is sufficiently low and that the model derived from these factors is free from the multi-collinearity problem, we calculated Pearson's correlation coefficients.

As Table 3 shows, the coefficients are all smaller than 0.2 except for the pair of Social Responsibility Building Disclosure and Corporation Characteristics. The correlation coefficient between these two variables is -0.369 as social responsibility and corporate governance might be slightly interlinked. Both factors are about relationships and social networks: The former stresses on fostering external relationships while the latter focuses on maintaining interior ones.

Table 3. Correlation tests between variables.

\begin{tabular}{ccccccc}
\hline & SEC & SRBD & CC & ALR & NIR & FIGR \\
\hline SEC & 1 & & & & & \\
SRBD & 0.014 & 1 & & & & \\
CC & -0.191 & -0.369 & 1 & & & \\
ALR & 0.007 & -0.151 & 0.146 & 1 & & \\
NIR & -0.096 & 0.140 & -0.187 & -0.154 & 1 & \\
FIGR & 0.052 & 0.027 & 0.060 & 0.027 & -0.127 & 1 \\
\hline
\end{tabular}

\subsection{Descriptive Statistics}

Table 4 provides descriptive statistics for our main variables. They are tested to reveal means and standard deviations of the default group versus the control group. T-tests for means in these 
two groups are also conducted to test whether the difference in each variable among groups is statistically significant.

Table 4. Descriptive statistics of two groups.

\begin{tabular}{cccccc}
\hline Indicators & \multicolumn{2}{c}{ Mean } & \multicolumn{2}{c}{ Std. Deviation } & $p$-Value \\
\hline & $\begin{array}{c}\text { The Default } \\
\text { Group }\end{array}$ & $\begin{array}{c}\text { The Control } \\
\text { Group }\end{array}$ & $\begin{array}{c}\text { The Default } \\
\text { Group }\end{array}$ & $\begin{array}{c}\text { The Control } \\
\text { Group }\end{array}$ \\
SEC & 1.036 & 0.871 & 0.462 & 0.569 & 0.055 \\
SRBD & 0.000 & 0.450 & 0.000 & 0.500 & 0.000 \\
CC & 0.758 & 0.259 & 0.441 & 0.432 & 0.000 \\
ALR & $78.460 \%$ & $63.919 \%$ & 0.196 & 0.144 & 0.000 \\
NIR & $-144.168 \%$ & $8.497 \%$ & 4.060 & 0.105 & 0.004 \\
FIGR & $-1.783 \%$ & $0.183 \%$ & 0.001 & 0.001 & 0.246 \\
\hline
\end{tabular}

The statistical analysis indicates that issuers of default bonds tend to have higher standard energy consumption (i.e., worse environmental efficiency), are less aware of social responsibility building disclosure, and are more likely to be a private enterprise.

As shown in Table 4, default corporations, on average, are about $13 \%$ less energy efficient than non-default ones, which is a relatively significant difference. One interesting finding is that while about half of non-default issuers disclose social responsibility building in their financial statements, almost no default issuers attempt or seem to be willing to reveal such information, which is an extremely significant difference. The mean of corporation characteristics of the default group is 0.758 , which means that about $75.8 \%$ of default bonds in the sample were issued by private enterprises, whereas only $25.9 \%$ of non-default bonds were issued by the private sector, resulting in a statistically significant difference.

Financially, default corporations generally have higher asset liability ratios (i.e., greater leverage rates), lower and often negative Net Income Ratio and lower growth rates. This fact represents that not only ESG governance capabilities are relatively weaker, but also financial managements are less stable and sustainable in those default issuers.

\section{Empirical Results}

The model to estimate the possibility of bond default is modified based on a Logistic Regression analysis. Logistic Regression is a non-linear multivariate model that deals with problems with a dichotomous dependent variable. One should also note that samples in a Logistic Regression model do not have to be normally distributed. This feature makes it suitable for simulating the determination of default.

The multivariate Logistic Regression model can be converted into a linear one, in which Maximum Likelihood Regression is applied to approximate parameters in the model:

$$
\operatorname{Logit}\left(P_{i}\right)=\ln \left(\frac{P_{i}}{1-P_{i}}\right)=b_{0}+b_{1} * X_{1 i}+b_{2} * X_{2 i}+\ldots+b_{k} * X_{k i}+e_{i}, i=1,2, \ldots, 99,
$$

Then the model can be further rearranged into the typical version of Logistic Regression Function:

$$
P_{i}=\frac{1}{1+\mathrm{e}^{-\left(\beta_{0}+\beta_{1} * X_{1 i}+\beta_{2} * X_{2 i}+\ldots+\beta_{k} * X_{k i}+\varepsilon_{i}\right)}}, i=1,2, \ldots, 99,
$$

where $P i$ is the possibility of issue i's default; $X_{1 i}$ to $X_{k i}$ are values of independent variables of issue $i ; \varepsilon_{i}$ represents the statistical error of the model.

In this model, the dependent variable is the default possibility of industrial bonds. The independent variables include Standard Energy Consumption, Social Responsibility Building Disclosure, Corporation Characteristics, Asset Liability Ratio, Net Income Ratio, and Fixed Investment Growth Rate. 
We completed a Logistic Regression to determine how and to what degree variables influence the default risk of the corporation and the bond. The final model was built after several iterations, providing results conforming to our preconceived ideas and intuitions.

$$
\begin{gathered}
S_{i}=\beta_{0}+\beta_{1} * S E C_{i}+\beta_{2} * S R B D_{i}+\beta_{3} * C C_{i}+\beta_{4} * A L R_{i}+\beta_{5} * N I R_{i}+\beta_{6} * F I G R_{i}+\varepsilon_{i}, \\
P_{i}=\frac{1}{1+\mathrm{e}^{-S_{i}}}, i=1,2, \ldots, 99,
\end{gathered}
$$

As Table 5 shows, corporations with worse Environmental Performance (or higher standard energy consumption), worse social responsibility building (or pay little attention to disclosing relevant information), worse corporate governance (or are privately owned), higher financial leverage (or greater Asset Liability Ratio), poorer financial profitability, smaller or even negative growth (or are in a shrinking industry), are prone to financial distress that may lead to bankruptcy or default.

Table 5. Estimations of coefficients and the result of T-test.

\begin{tabular}{ccc}
\hline Factors & Indicators & Coefficient \\
\hline Environmental Performance & SEC & $4.206^{* *}$ \\
Social Responsibility & SRBD & -17.939 \\
Corporate Governance & CC & $5.203^{* *}$ \\
Leverage & ALR & $0.106^{* *}$ \\
Profitability & NIR & $-0.348^{* * *}$ \\
Growth & FIGR & $-18.404^{* *}$ \\
& Constant & $-15.134^{* *}$ \\
\hline
\end{tabular}

Note: ${ }^{*} p<0.1,{ }^{* *} p<0.05,{ }^{* * *} p<0.01$.

Results in Table 5 show that corporations that have ESG concerns are prone to bond default and that corporations with ESG strengths enjoy lower default risks. Why does the market value these factors? The rationale for the model result is discussed below.

Environmental performance has become more crucial in daily operations, such that the board and management of each corporation should not ignore it. Reasons can be twofold. First, from the funding aspect, as green finance has been introduced to China, the government and financial institutions have become gradually aware of the importance of environmental sustainability. Therefore, policies have been implemented to support environmentally friendly companies or business behaviors via generous financial incentives, including offering concessionary interest rates that are lower than the market rate and opening "the Green Channel" for debt borrowers that can efficiently lower issuing costs and shorten the issuing period for green bond issuers. At the same time, barriers and limitations have been set for those "brown" corporations that are considered polluting or backward in technique. Under these circumstances, energy consumption is a factor that greatly and directly impacts funding abilities, costs, and corporations' credit. Second, from the legal aspect, as citizens become more environmentally conscious, corporations that are reportedly oblivious of environmental protection or worse, deliberately contaminate surrounding neighborhoods, would eventually be sued for breaching legal responsibilities and banished by the market. Environmental performance, in this sense, can result in reputational risks and strategic risks.

The social responsibility factor, though not significant statistically, is kept in the model as it might become more important in the following years. A modified Code of Corporate Governance for Listed Companies was released in September 2018. It emphasized that corporations should benefit stakeholders while taking actions to protect the environment and show a sense of social responsibility via public charity. As newly published policies in this field suggest, ESG disclosure and capacity building are going to become mainstream in global capital markets. By adhering to these policies, a corporation's deep social concern works as a signal that, in return, enables the corporation to gain better human resources and more sustainable and stable social networks with the community. 
If treated with extra care, such attention can be converted into a competitive edge, which can reduce the possibility of default.

Corporation characteristics, which work as the corporate governance variable, are related to the default possibility of the bond. In fact, of all the bonds that have defaulted in Chinese capital markets, private enterprise bonds constitute about $75 \%$, which is asymmetrically larger than the total share of private enterprise bonds (about $25 \%$ of total bond issues) in the market. The reasons are complicated. First, private enterprises tend to be smaller in scale and occupy slimmer market shares, resulting in smaller amounts of net cash flow to pay back debts, especially during economic downturns. Second, compared to state-owned enterprises, private enterprises have weaker connections to the government. This case might leave them at a disadvantage to acquire better human resources and sometimes essential inside information. Third, since founders or management in private enterprises have more discretion of the corporation than those in other corporations, private Chinese enterprises are prone to arbitrariness, which might lead to greater uncertainty, especially during fluctuating market periods. Finally, generally speaking, while state-owned enterprises in China are more hierarchical and generally well-organized, private corporations encounter fewer outside limitations and restraints, resulting in a weaker willingness to form strict codes of conduct.

Leverage, profitability and growth factors, as previous research predicted, play vital roles in the determination of default possibility. Corporations with higher asset liability ratios are required to pay back large sums of interest, while the ones that mainly rely on equity enjoy lower capital costs and normally are financially slacker. Since highly leveraged non-financial institutions or corporations face greater financial risks, small disturbances in the market can generate huge uncertainties on the profitability, making each sum of interest payment a burden too heavy to bear. Profitability is the economic foundation that the corporation is built on, since decent profits normally guarantee the capability of on-schedule payments. Industrial growth rate, on the other hand, reveals the overall condition of the industry. Since corporations are highly interlinked within the same industry, smaller fixed investments in the industry would hinder the development of the industry and each corporation. Adverse investment willingness in the industry would eventually sap the financial condition of each corporation. A higher default risk would then be inevitable.

\section{Model's Robustness and Predictability Tests}

The model, which was developed based on the Estimation Group and tested by comparing the estimated default likelihood and the actual result, underwent the Hosmer-Lemeshow Test. Results of statistical tests on the model are presented in Table 6.

Table 6. Results of statistical tests on the model.

\begin{tabular}{ccccc}
\hline \multicolumn{2}{c}{ Pseudo R-Squareds } & \multicolumn{2}{c}{ Hosmer-Lemeshow Test } \\
\hline Cox \& Snell R-Squared & Nagelkerke R-Squared & Chi-Square & Df & $p$-Value \\
\hline 0.669 & 0.899 & 10.195 & 8 & 0.252 \\
\hline
\end{tabular}

Overall, the model demonstrates statistical significance and reliability, since the Nagelkerke $\mathrm{R}$-squared of the model is as high as 0.899 , showing the goodness-of-fit can be satisfactory. Meanwhile, the Hosmer-Lemeshow Test showed a $p$-value of 0.252 . One should note that the null hypnosis of this test is that predictions of the tested model are not statistically different from the ones in reality. In other words, since the null hypnosis cannot be rejected, the appropriate interpretation is that there is no reason to deny the statistical validity of the model.

The significance of each variable in the model is also tested to verify that each indicator is indispensable in the determination of default risks. Table 5 shows the significance test result corresponding to each variable. As the result suggests, each variable except for Social Responsibility is statistically significant. 
Notably, the result shows that corporations in typical polluting industries, including manufacturing, mining, electricity and the thermal production industry, are statistically prone to default, since the average corporation energy consumption in these industries tends to be much higher than others, especially those that rely mostly on intellectual property and human resources, for example, the cultural and entertainment industry.

Social responsibility, on the other hand, seems to be less significant. One possible reason might be that corporations with lower default risks are naturally and voluntarily more conscious about the importance of keeping the "outsiders", including bondholders, informed. Therefore, partly, this variable can be explained by other factors in the model. An intriguing phenomenon can, therefore, be verified that while some non-default corporations disclose information about social responsibility building in their financial statements, default issuers, regardless of their listing status, are reluctant to reveal this information in any form, leading to the only deduction that sufficient effort was not made during daily operations. However, this finding does not necessarily equalize the idea that social responsibility is useless in modern corporate credit risks managements. On the contrary, this outcome suggests that social responsibility is a related, if not vital, factor in the all-round development of a corporation.

Corporate governance, as we predict, is a significant determinant in the model, considering that private corporations are stuck in tricky positions where market shares, corporation structures, information asymmetry, and scandal exposures are more unfavorable than state-owned enterprises.

The result that financial factors are significant in the model comes as no surprise, since poorly operated corporations will eventually encounter financial distress. These corporations might have difficulty in accumulating sufficient cash flow for interest payments and managing daily operations, generating negative feedback loops that contribute to bond default.

In order to examine the predictability of the model, type I and II errors are estimated through applying the result of Logistic Regression to both the Estimation Sample and the Holdout Sample.

As Table 7 shows, the model has a composite accuracy of $94.9 \%$ for the Estimation Sample, with a $5.3 \%$ possibility of making type I error and a $4.8 \%$ possibility of making type II error.

Table 7. Model accuracy and predictability tests on Estimation Sample.

\begin{tabular}{lcccc}
\hline \multirow{2}{*}{ Observed } & \multicolumn{2}{c}{ Predicted } & \multirow{2}{*}{ Percentage Correct } \\
\cline { 3 - 4 } & Non-Default & Default & \\
\hline \multirow{3}{*}{} & Non-default & 54 & 3 & 94.7 \\
& Default & 2 & 40 & 95.2 \\
& Overall Percentage correct & & 94.9 \\
\hline
\end{tabular}

The randomly selected the Holdout Sample is applied to further examine the applicability and predictability of the model. As Table 8 shows, the model correctly predicts all non-default bonds, revealing that the model can avoid type I error when testing the Holdout Sample. For the default group, the model correctly predicts 17 out of the total 20 issuances, showing that estimated type II error of the model is $15 \%$. Overall, the model has an accuracy of $93.8 \%$ while testing on the Holdout Sample, which is close to that of the Estimation Sample, meaning the model has relatively stable and credible predictability.

Table 8. Model accuracy and predictability tests on Holdout Sample.

\begin{tabular}{ccccc}
\hline & & \multicolumn{2}{c}{ Predicted } & \multirow{2}{*}{ Percentage Correct } \\
\cline { 3 - 4 } & & Non-Default & Default & \\
\hline \multirow{2}{*}{ Observed } & Non-default & 28 & 0 & 100 \\
& Default & 3 & 17 & 85 \\
& Overall Percentage correct & & 94 \\
\hline
\end{tabular}




\section{Conclusions and Implications}

This study applied up-to-date statistics from the Chinese capital market. It also covered several factors, each delineating one aspect of the ESG governance ability or the overall financial status of the issuer. A Logistic Regression model was then built to predict the possibility of default for each sample. This study has a certain degree of particularity and financial significance, for it took industrial factors and ESG factors into account when determining the likelihood of industrial bond default.

However, due to the scarcity of public micro-level ESG data on the Chinese bond market, proxies employed in this paper seem to be fairly limited. Profound and extensive studies on influences of ESG performance on bond credit risks can be carried out when amplified and diversified ESG data are available after mandatory ESG disclosure policies are implemented in China.

Based on the result of the study, several implications and policy suggestions can be generated. There are four implications in this study. For potential bond investors, this model can present an approximate default likelihood in advance, offering investors a reference when they are making investment decisions for their portfolios. For issuers, clear evidences from this study demonstrate that under current circumstances, financial performance is not the sole criterion and determinant of all-round developments. Integrated standards and aims, including environmental protection, social responsibility, and corporate governance, should be considered when making strategic decisions, since these factors are significant in influencing the credit and operational risk of the corporation. For rating agencies, this model can work as a reference when they are commissioned to provide ratings for intended bond issuers. For the capital market, this model assists in bond pricing, since the value of the bond is closely connected to the credit risk of the bond and its issuer. In order to reduce the general default rate of Chinese industrial bonds and prompt researches in related fields, applicable policies should be formulated. Standardizing, regulating, and enforcing bond issuer ESG-related information disclosure is instrumental not only in further research but also in prompting poorly-managed corporations to enhance their ESG governance capabilities and pursue sustainable businesses. Meanwhile, corporate ESG databases should be constructed for better public regulations. Additionally, in order to prevent bond degradations, regulators should formulate ESG regulations with comprehensive instructions for corporations to consolidate their ESG governance capabilities.

Author Contributions: Conceptualization, R.Z.; methodology, Y.X.; software, P.L.; validation, P.L., R.Z. and Y.X.; formal analysis, P.L.; investigation, P.L.; resources, R.Z.; data curation, P.L.; writing—original draft preparation, P.L; writing-review and editing, R.Z. and Y.X.; supervision, R.Z.; project administration, R.Z.; funding acquisition, R.Z. All authors have read and agreed to the published version of the manuscript.

Funding: This work is partially supported by the National Natural Science Foundation of China under Grant No. 71871062 and the humanities and Social Science Foundation of the Ministry of Education under Grant No.16YJA630078.

Conflicts of Interest: The authors declare no conflict of interest.

\section{References}

1. Kolari, J.W.; Apilado, V.P. The cyclical effect of default risk on industrial bond yields. J. Econ. Bus. 1985, 37, 311-325. [CrossRef]

2. Huffman, S.P.; Ward, D.J. The prediction of default for high yield bond issues. Rev. Financ. Econ. 1996, 5, 75-89. [CrossRef]

3. Deng, X.; Cheng, X. Can ESG indices improve the enterprises' stock market performance?-An empirical study from China. Sustainability 2019, 11, 4765. [CrossRef]

4. Bing, T.; Li, M. Does CSR signal the firm value? Evidence from China. Sustainability 2019, 11, 4255. [CrossRef]

5. Qiu, M.; Yin, H. An analysis of enterprises' financing cost with ESG performance under the background of ecological civilization construction. J. Quant. Tech. Econ. 2019, 36, 108123.

6. Jitmaneeroj, B. Reform priorities for corporate sustainability: Environmental, social, governance, or economic performance? Manag. Decis. 2016, 54, 1497-1521. [CrossRef] 
7. Dorfleitner, G.; Halbritter, G.; Nguyen, M. The risk of social responsibility-Is it systematic? J. Sustain. Financ. Investig. 2016, 6, 1-14. [CrossRef]

8. Dorfleitner, G.; Halbritter, G.; Nguyen, M. Measuring the level and risk of corporate responsibilityAn empirical comparison of different ESG rating approaches. J. Asset Manag. 2015, 16, 450-466. [CrossRef]

9. Sharfman, M.P.; Fernando, C.S. Environmental risk management and the cost of capital. Strateg. Manag. J. 2008, 29, 569-592. [CrossRef]

10. Halkos, G.; Sepetis, A. Can capital markets respond to environmental policy of firms? Evidence from Greece. Ecol. Econ. 2007, 63, 578-587. [CrossRef]

11. Chava, S. Environmental externalities and cost of capital. Manag. Sci. 2014, 60, 2223-2247. [CrossRef]

12. Schneider, T.E. Is environmental performance a determinant of bond pricing? Evidence from the US pulp and paper and chemical industries. Contemp. Account. Res. 2011, 28, 1537-1561. [CrossRef]

13. Lins, K.V.; Servaes, H.; Tamayo, A. Social capital, trust, and corporate performance: How CSR helped companies during the financial crisis. J. Financ. 2017, 72, 1785-1823. [CrossRef]

14. Ghoul, S.E.I.; Guedhami, O.; Kwok, C.C.; Mishra, D.R. Does corporate social responsibility affect the cost of capital? J. Bank. Financ. 2011, 35, 2388-2406. [CrossRef]

15. Attig, N.; Ghoul, S.E.I.; Guedhami, O.; Suh, J. Corporate social responsibility and credit ratings. J. Bus. Ethics 2013, 117, 679-694. [CrossRef]

16. Ge, W.; Liu, M. Corporate social responsibility and the cost of corporate bonds. J. Account. Public Pol. 2015, 34, 597-624. [CrossRef]

17. Oikonomou, I.; Brooks, C.; Pavelin, S. The effects of corporate social performance on the cost of corporate debt and credit ratings. Financ. Rev. 2014, 49, 49-75. [CrossRef]

18. Goss, A.; Roberts, G.S. The impact of corporate social responsibility on the cost of bank loans. J. Bank. Financ. 2011, 35, 1794-1810. [CrossRef]

19. Chava, S.; Kumar, P.; Warga, A. Managerial agency and bond covenants. Rev. Financ. Stud. 2009, 23, 1120-1148. [CrossRef]

20. Shi, G.; Sun, J. Corporate bond covenants and social responsibility investment. J. Bus. Ethics 2015, 131, 285-303. [CrossRef]

21. Sengupta, P. Corporate disclosure quality and the cost of debt. Account Rev. 1998, 73, 459-474.

22. Bozec, Y.; Bozec, R. Corporate governance quality and the cost of capital. Int. J. Corp. Gov. 2011, 2, 217. [CrossRef]

23. Zhu, F. Corporate governance and the cost of capital: An international study. Int. Rev. Financ. 2014, 14, 393-429. [CrossRef]

24. Ge, W.; Kim, J.B.; Song, B.Y. Internal governance, legal institutions and bank loan contracting around the world. J. Corp. Financ. 2012, 18, 413-432. [CrossRef]

25. Poshakwale, S.; Courtis, J.K. Disclosure level and cost of equity capital: Evidence from the banking industry. Manag. Decis. Econ. 2005, 26, 431-444. [CrossRef]

26. Fich, E.M.; Slezak, S.L. Can corporate governance save distressed firms from bankruptcy? An empirical analysis. Rev. Quant. Financ. Account. 2008, 30, 225-251. [CrossRef]

27. Chen, K.C.W.; Chen, Z.; Wei, K.C.J. Legal protection of investors, corporate governance, and the cost of equity capital. J. Corp. Financ. 2009, 15, 273-289. [CrossRef]

28. Fernando, J.M.R.; Li, L.; Hou, Y. Corporate governance and default prediction: A reality test. Appl. Econ. 2019, 51, 2669-2686. [CrossRef]

29. Switzer, L.N.; Wang, J.; Zhang, Y. Effect of corporate governance on default risk in financial versus nonfinancial firms: Canadian evidence. Can. J. Adm. Sci. 2018, 35, 313-328. [CrossRef]

30. Heinkel, R.; Kraus, A.; Zechner, J. The effect of green investment on corporate behavior. J. Financ. Quant. Anal. 2001, 36, 431-449. [CrossRef]

31. Du, X.; Weng, J.; Zeng, Q.; Chang, Y.; Pei, H. Do lenders applaud corporate environmental performance? Evidence from Chinese private-owned Firms. J. Bus. Ethics 2017, 143, 179-207. [CrossRef]

32. Datta, D.K.; Rajagopalan, N. Industry structure and CEO characteristics: An empirical study of succession events. Strateg. Manag. J. 1998, 19, 833-852. [CrossRef]

33. Christopher, S.J.; Li, S. Do employee dimension ratings reflect employee performance? Evidence from MSCI's ESG database. Appl. Econ. Lett. 2019, 26, 1182-1185. 
34. Tarmuji, I.; Maelah, R.; Tarmuji, N.H. The impact of Environmental, Social and Governance Practices (ESG) on economic performance: Evidence from ESG score international. J. Trade Econ. Financ. 2016, 7, 67-74. [CrossRef]

35. Velte, P. Does ESG performance have an impact on financial performance? Evidence from Germany. J. Glob. Responsib. 2017, 8, 169-178. [CrossRef]

36. Duque-Grisales, E.; Aguilera-Caracuel, J. Environmental, social and governance (ESG) scores and financial performance of multilatinas: Moderating effects of geographic international diversification and financial slack. J. Bus. Ethic 2019, 1-20. [CrossRef]

37. Mercedes, R.; Eva, M.S.; Alberto, A.L.; Susana, B. Influence of ESGC indicators on financial performance of listed travel and leisure companies. Sustainability 2019, 11, 5529.

38. Amel-Zadeh, A.; Serafeim, G. Why and how investors use ESG information: Evidence from a global survey. Financ. Anal. J. 2018, 74, 87-103. [CrossRef]

39. Aouadi, A.; Marsat, S. Do ESG controversies matter for firm value? Evidence from international data. J. Bus. Ethics 2018, 151, 1027-1047. [CrossRef]

40. Iamandi, I.; Constantin, L.; Munteanu, S.; Bogdan, C. Mapping the ESG behavior of european companies. A holistic kohonen approach. Sustainability 2019, 11, 3276. [CrossRef]

41. Freeman, R.E.; Wicks, A.C.; Parmar, B. Stakeholder theory and the corporate objective revisited. Organ. Sci. 2004, 15, 364-369. [CrossRef]

42. Duan, H.; Chik, A.; Bin, R. Institutional environment, political connection and financial constraints-Evidence from private enterprise in China. Bus. Manag. Res. 2012, 1, 133-140. [CrossRef]

(C) 2020 by the authors. Licensee MDPI, Basel, Switzerland. This article is an open access article distributed under the terms and conditions of the Creative Commons Attribution (CC BY) license (http://creativecommons.org/licenses/by/4.0/). 